ARTICLE HISTORY: Received: August: 7, 2021 Accepted: September 28, 2021 Published: October 4, 2021

ВЫБОР СОРТОВ ОВОЩНЫХ КУЛЬТУР ДЛЯ СУШКИ

Каримова Д.З.

Ассистент, Ургенчский государственный университет, 2. Ургенч, Хорезмская область, Республика Узбекистан.

Акрамов У.И.

К.с.х.н., доцент ТГАУ

2. Ургенч, Хорезмская область, Республика Узбекистан

\title{
SELECTION OF VARIETIES OF VEGETABLES FOR DRYING
}

Karimova D.Z.

Assistant, Urgench State University,

Urgench city, Khorezm region, Republic of Uzbekistan.

Akramov U.I.

Candidate of Agricultural Sciences, Associate Professor, TSAU

Urgench city, Khorezm region, Republic of Uzbekistan.

Аннотация. В данной статье рассматривается выбор сортов овощных культур для сушки в Хорезмской области.

Abstract. This article discusses the choice of varieties of vegetable crops for drying in the Khorezm region.

Ключевые слова: vegetable varieties, vegetable crops, drying of vegetable crops

Keywords: сорта овощных культур, овощные культуры, сушка овощных культур

Введение. Важнейшие задачи по обеспечению питанием населения состоят в расширении ассортимента продуктов, обновлении состава рационов и обогащении его продуктами повышенной пищевой ценности и профилактической направленности. В настоящее время объектами промышленной сушки являются сочные материалы, к которым относятся овощи и плоды. Известно, что для нормальной жизнедеятельности микроорганизмов необходима вода (для жизнедеятельности бактерий требуется не менее $30 \%$ влаги, плесеней $15 \%$, а для прорастания спор плесеней нужна еще более высокая влажность) [1, с. 312; 2, с.190].

Выход сушеного продукта зависит, прежде всего, от такого показателя как содержание сухого вещества в исходном продукте. Но сухое вещество - это, прежде всего каркас, состоящий преимущественно из минеральных веществ и клетчатки. А в сушеных овощах остается еще и вода, в которой будут растворены или с которой будут химически связаны такие ценные вещества как углеводы и витамины [4, с. 352].

Условия приготовления однородного сушеного продукта конкурентоспособного качества состоит в том, чтобы надежно отобранные, пригодные для сушки сорта выращивались строго изолированно и не смешивались с сортами общего пользования. Например, лук репчатый используют для сушки только острых сортов, которые содержат не менее $14 \%$ сухих веществ, у моркови корнеплоды полудлинные, усечено-конические или цилиндрические, среднекрупные, от оранжево-красного до красного цвета, без заметной сердцевины и без грубых сосудисто-волокнистых пучков, с содержанием сухих веществ не менее 13\%, из которых сахара составляют 4-6\%, в сортах свеклы, предназначенной для сушки, должно быть сухих веществ не менее $14 \%$, из которых сахара должны составлять не менее 8\% [3, с. 5-7; 5, 198 с.].

Однако в Узбекистане стоит, вопросы определены, наиболее пригодные сорта столовой моркови и свеклы, лука репчатого среди районированных сортов для сушки, влияния различных способов и продолжительности нагрева на качество сушеной продукции, а также влияния формы нарезки сырья и бланширования на качество готовой продукции.

Результаты исследования. Для того что бы произвести выбор сортов овощного сырья, оптимально пригодных для сушки в Хорезмской области, собраны данные по хозяйствам Ургенчского района, которые свидетельствуют о том какие сорта моркови и свеклы столовой, а также лука репчатого имеют наибольшие посевные площади в районах выращивания. Выяснилось, что в области выращиваются преимущественно столовые сорта корнеплодов, а сорта лука - преимущественно полуострые (за исключением сорта Халцедон). Затем дан сравнительный анализ сортов по таким критериям как урожайность, содержание сухих веществ, содержание сахаров и отдельных витаминов. Для сравнительного анализа приводятся данные таблице 1.

Поэтому выбор сортов для сушки будет производиться не только по наибольшему количеству сухого вещества в сырье, но и по наибольшему содержанию других физиологически ценных веществ, таких как 
витамины и углеводы. По наибольшему содержанию сухих веществ лидерами являются: сорта моркови Шантанэ 2461, Зийнатли и Фаравон; сорта свеклы столовой - Ягона, Бордо 237 и Болтарди; сорта лука репчатого - Истиқбол, Халцедон и Еллоу Спаниш.

Наибольшее содержание общего сахара наблюдается у сортов: моркови - Зийнатли, Фаравон и Шантанэ 2461; свеклы столовой - Болтарди, Ягона и Бордо 237; лука репчатого - Халцедон, Сумбула и Истиқбол.

Таблица 1.

Химические состав сортов овощных культур, имеющих наибольшие посевные площади в Хорезмской области

\begin{tabular}{|c|c|c|c|c|c|}
\hline \multirow[b]{2}{*}{ Сорта овощных культур } & \multirow{2}{*}{$\begin{array}{c}\text { Урожай, } \\
\text { ц/га }\end{array}$} & \multicolumn{4}{|c|}{ Содержание } \\
\hline & & $\begin{array}{c}\text { сухого } \\
\text { вещества, \% }\end{array}$ & $\begin{array}{c}\text { общего } \\
\text { сахара, \% }\end{array}$ & $\begin{array}{c}\text { каротина, } \\
\text { мг\% } \%\end{array}$ & $\begin{array}{c}\text { витамин C, } \\
\text { мг \% }\end{array}$ \\
\hline \multicolumn{6}{|c|}{ Морковь } \\
\hline Мирози кизил 228 & 285 & 8,9 & 5,7 & 10,7 & 3,84 \\
\hline Шантанэ 2461 & 228 & 13,3 & 6,9 & до 17,2 & 4,05 \\
\hline Барака & 356 & 10,9 & 6,5 & до 15,0 & 3,95 \\
\hline Зийнатли & 412 & 10,8 & 7,0 & до 13,8 & 4,26 \\
\hline Фаравон & 525 & 12,2 & 7,4 & до 12,1 & 4,00 \\
\hline \multicolumn{6}{|c|}{ Свекла столовая } \\
\hline Бордо 237 & 456 & 18,6 & 12,7 & - & 8,07 \\
\hline Болтарди & 507 & 16,1 & 13,4 & - & 7,87 \\
\hline Бикорес & 412 & 14,0 & 8,8 & - & 7,56 \\
\hline Диёр & 658 & 12,9 & 10,1 & - & 7,93 \\
\hline Ягона & 680 & 19,0 & 13,3 & - & 8,44 \\
\hline \multicolumn{6}{|c|}{ Лук репчатый } \\
\hline Халцедон & 454 & 11,1 & 6,3 & - & 8,59 \\
\hline Истиқбол & 310 & 11,6 & 5,7 & - & 8,43 \\
\hline Банко & 350 & 7,3 & 4,1 & - & 7,54 \\
\hline Еллоу Спаниш & 380 & 8,7 & 5,0 & - & 7,81 \\
\hline Сумбула & 420 & 7,5 & 6,7 & - & 7,40 \\
\hline Каба 132 & 315 & 8,4 & 4,8 & - & 8,03 \\
\hline
\end{tabular}

По содержанию каротина лидируют следующие сорта моркови - Шантанэ 2461, Барака и Зийнатли. Естественно, что на посевных площадях целесообразно получать наибольший товарный урожай. Наибольшую товарную урожайность имеют сорта: моркови - Фаравон, Шантанэ 2461 и Зийнатли; свеклы столовой - Ягона, Бордо 237 и Диёр; лука репчатого - Банко, Халцедон и Еллоу Спаниш.

По совокупности показателей лучшими сортами для сушки являются: сорта моркови - Зийнатли, Шантанэ 2461 и Фаравон; сорта свеклы столовой - Ягона, Бордо 237 и Болтарди; сорта лука репчатого - Халцедон, Истиқбол и Еллоу Спаниш.

Если же поставить цель выделить один оптимально пригодный для сушки сорт для каждого вида овощей в Хорезмской области, то это, безусловно: сорт моркови столовой - Зийнатли, сорт свеклы столовой - Ягона, сорт лука репчатого - Халцедон. Характеристика выделенных сортов полностью соответствует требованиям к сортам овощей, предназначенных для сушки.

Выводы. Таким образом, из всех видов сушеной овощной продукции наибольшим спросом пользуются лук столовый, морковь и свекла столовые, а также из районированных и выращиваемых в Хорезмской области сортов по товарной урожайности, содержанию сухих веществ, витаминов и сахаров лучшими для сушки являются следующие сорта овощных культур: моркови столовой - Зийнатли, свеклы столовой - Ягона, лука репчатого - Халцедон.

\section{Список использованной литературы:}

1. Базарова, Л.А. Исследование продовольственных товаров / Базарова Л.А., Боровикова Л.А. /. - М.: Экономика, 1986. $-312 \mathrm{c}$.

2. Воскобойников, В.А. Сушеные овощи и фрукты / Воскобойников В.А., Гуляев В.Н., Кац З.А., Попов О.А. /. - М.: Пищевая промышленность, 1980. -190 с.

3. Гинзбург, А.С. Основы теории и техники сушки пищевых продуктов 
/ Гинзбург А.С. / Пищевая промышленность. 1999. - №4. - С. 5-7.

4. Загибалов, А.Ф. Технология консервирования плодов и овощей и контроль качества продукции /

Загибалов А.Ф., Зверькова А.С., Титова А.А., Флауменбаум Б.Л. /. - М.: Агропромиздат, 1992. - 352 с.

5. Кац 3.А. Производство сушеных овощей, картофеля и плодов / Кац 3.А. /. - М.: Пищевая промышленность, 1976. - 198 с.

\section{References}

1. Bazarova, L.A. Issledovaniye prodovol'stvennykh tovarov / Bazarova L.A., Borovikova L.A. /. - M.: Ekonomika, 1986. $-312 \mathrm{p}$.

2. Voskoboynikov, V.A. Sushenyye ovoshchi i frukty / Voskoboynikov V.A., Gulyayev V.N., Kats Z.A., Popov O.A. /. - M.: Pishchevaya promyshlennost', 1980. - 190 p.

3. Ginzburg, A.S. Osnovy teorii i tekhniki sushki pishchevykh produktov / Ginzburg A.S. / Pishchevaya promyshlennost'. 1999. - №4. - pp. 5-7.

4. Zagibalov, A.F. Tekhnologiya konservirovaniya plodov i ovoshchey i kontrol' kachestva produktsii / Zagibalov A.F., Zver'kova A.S., Titova A.A., Flaumenbaum B.L. /. - M.: Agropromizdat, 1992. - 352 p.

5. Kats Z.A. Proizvodstvo sushenykh ovoshchey, kartofelya i plodov / Kats Z.A. /. - M.: Pishchevaya promyshlennost', 1976. $-198 \mathrm{p}$. 